\title{
Chapter 6 \\ Genetic Variation and Its Geographical \\ Distribution in Aegilops caudata L.: \\ Morphology, Hybrid Sterility \\ and Gametocidal Genes
}

\author{
Shoji Ohta and Naomi Yasukawa
}

\begin{abstract}
Aegilops caudata L. is a diploid wild relative of wheat with the main distribution in the northeastern Mediterranean basin from Greece to northern Iraq. Two varieties are taxonomically described in this species based on spike morphology. In the present work, to elucidate the geographical differentiation pattern of the species, the geographical distribution of the two varieties was reviewed, 35 accessions derived from the entire distribution area were crossed with the four Tester lines, two varieties derived from their sympatric stands on the Aegean Islands were crossed with each other, and their $\mathrm{F}_{1}, \mathrm{~F}_{2}$ and/or $\mathrm{BC}_{1} \mathrm{~F}_{1}$ populations were examined. It became clear that the present distribution area of Ae. caudata can be divided into the western and eastern regions with the border in the mountains lying between West Anatolia and Central Anatolia: the western and eastern accessions are isolated not only geographically but also reproductively by hybrid sterility caused by gametocidal-like genes, and the morphology of var. typica is controlled by two different genotypes in the western and eastern regions. It was suggested that Ae. caudata occurred in the two isolated refuges during the maximum glacial period, the Aegean region and the western Levant or some sheltered habitats in the East Taurus/ Zagros mountains arc, and that the latter population now occurs in the eastern region while the former now occupies the western region of the distribution.
\end{abstract}

The genus Aegilops L. consists of about 25 species, and the morphological variation and the geographical distribution of the each species and the infraspecific taxa were described in detail in 1920s (Zhukovsky 1928; Eig 1929). And two new taxonomic systems were recently published (Hammer 1980; van Slageren 1994). However, the treatment of infraspecific taxa differed so much from author to author. Genetic reassessment of infraspecific taxa is essential to biosystematic approach to the better

\footnotetext{
S. Ohta $(\varangle) \cdot$ N. Yasukawa

Department of Bioscience, Fukui Prefectural University, Fukui, Japan

e-mail: ohta@fpu.ac.jp
} 
understanding of the diversity and speciation process of the each species, because some infraspecific taxa are phylogenetically significant but others are not. Aegilops caudata L. (syn. Ae. markgrafii (Greuter) Hammer) is a diploid wild relative of wheat. Two varieties are taxonomically described in this species based on spike morphology, var. typica with a well-developed awn on the empty glumes of only apical spikelets and var. polyathera Boiss. with an awn on the empty glumes of both the apical and lateral spikelets.

In the present work, to elucidate the geographical differentiation pattern of $A e$. caudata, the geographical distribution of the two varieties was reviewed, 35 accessions derived from the entire distribution area were crossed with the four Tester lines, two varieties derived from their sympatric stands on the Aegean Islands were crossed with each other, and their $\mathrm{F}_{1}, \mathrm{~F}_{2}$ and/or $\mathrm{BC}_{1} \mathrm{~F}_{1}$ populations were examined.

\section{Geographical Distribution of the Two Varieties}

Ae. caudata distributes from the southern Balkan Peninsula to Afghanistan with its main distribution in the northeastern Mediterranean basin from Greece to northern Iraq (Eig 1929; Bor 1968, 1970; Tutin and Humphries 1980). Based on the geographical distribution of the two varieties described in the literature (de Halácsy 1904; Hayek 1927; Eig 1929; Rechinger 1943; Bor 1968, 1970; Tanaka 1983a) and the collection lists published by Kyoto University (Tanaka 1983b; Sakamoto 1986), the main distribution area of the species can be divided into the three geographical regions according to the geographical division by Davis (1965): (1) The Greek mainland, the Aegean Islands and West Anatolia, where the two varieties occur with the predominant occurrence of var. typica, and their sympatric stands are common; (2) South Anatolia, East Anatolia, Iraq and Syria, where the two varieties occur but their sympatric stands are rare; and (3) Central Anatolia, where var. polyathera occurs exclusively.

\section{Hybrid Sterility}

\section{Cytogenetic Differentiation into Western and Eastern Geographical Groups}

Thirty-five accessions derived from the entire distribution area were crossed with the four Tester lines whose $F_{1}$ hybrids were highly sterile (Tanaka et al. 1967; Ohta 1992). Pollen fertility in the $F_{1}$ hybrids obtained from a total of 134 cross combinations varied from $0 \%$ to $96.3 \%$ (Table 6.1), and it was significantly correlated with their seed fertility by open-pollination $(r=0.786)$. The fertility in the $\mathrm{F}_{1}$ hybrids was correlated with the geographical origin of the parental accessions. Based on the 
6 Genetic Variation and Its Geographical Distribution in Aegilops caudata L.....

Table 6.1 Pollen fertility (\%) in the $\mathrm{F}_{1}$ hybrids between the four Testers and the 35 accessions of Ae. caudata from its entire distribution area (Ohta 2000)

\begin{tabular}{|c|c|c|c|c|c|c|c|}
\hline Region & Site no. & $\begin{array}{l}\text { Accession } \\
\text { no. }(\mathrm{KU})\end{array}$ & Variety $^{\mathrm{a}}$ & Tester $\mathrm{A}^{\mathrm{b}}$ & Tester B & Tester C & Tester D \\
\hline \multirow[t]{9}{*}{ Aegean Islands } & 1 & 12044B & $P$ & 0 & 0 & 0 & 25.0 \\
\hline & 2 & 12055B & $P$ & 0 & 0 & 14.5 & 83.5 \\
\hline & 3 & 12155B & $P$ & 0 & 0 & 0 & 69.1 \\
\hline & 4 & $12162 \mathrm{~A}$ & $T$ & 0 & 0 & 0 & 72.2 \\
\hline & 5 & $12163 \mathrm{~A}$ & $T$ & 0.1 & 0 & 0.8 & 96.3 \\
\hline & 6 & 12073A & $T$ & 0 & 0.1 & 0 & 0 \\
\hline & 7 & 12100B & $P$ & 0 & 15.1 & 42.6 & 86.3 \\
\hline & 8 & 12177B & $P$ & 0 & 0.1 & 8.9 & 56.0 \\
\hline & 9 & $12121 \mathrm{~A}$ & $T$ & 0 & 0.3 & 0.2 & 0.1 \\
\hline \multirow[t]{3}{*}{ West Anatolia } & 10 & 11401 & $T$ & 0 & 0 & 13.7 & 68.8 \\
\hline & 11 & 11403 & $T$ & 0 & No obs & 22.7 & 8.9 \\
\hline & 12 & 12169 & $T$ & 0.8 & 0.2 & 20.3 & 36.9 \\
\hline \multirow[t]{8}{*}{ Central Anatolia } & 13 & 5853 & $P$ & 0 & 17.8 & 0 & No obs \\
\hline & 14 & 5854 & $P$ & No obs & 51.8 & 0 & 0 \\
\hline & 15 & 5859 & $P$ & No obs & 65.4 & 0 & 0 \\
\hline & 16 & 5860 & $P$ & 13.1 & 0 & 0 & 0 \\
\hline & 17 & 5863 & $P$ & 0.1 & 31.3 & 0 & 0 \\
\hline & 18 & 5888 & $P$ & 0.2 & 95.5 & 0 & 0 \\
\hline & 19 & 5896 & $P$ & No obs & 66.9 & 0 & 0 \\
\hline & 20 & 12165 & $P$ & 10.3 & 1.5 & 0 & 0 \\
\hline \multirow[t]{3}{*}{ South Anatolia } & 21 & 5867 & $P$ & 14.1 & 28.9 & 0 & 0 \\
\hline & 22 & 5897 & $P$ & 62.5 & 0 & No obs & No obs \\
\hline & 23 & 5899 & $P$ & 93.3 & 0.5 & 0 & 3.5 \\
\hline \multirow[t]{9}{*}{ East Anatolia } & 24 & 5484 & $P$ & 24.2 & 0 & 0 & 0 \\
\hline & 25 & 5485 & $T$ & 0 & 61.0 & 0 & 0 \\
\hline & 26 & 5489 & $T$ & 27.0 & 19.3 & 0 & 0 \\
\hline & 27 & 5490 & $P$ & 69.7 & 9.4 & 0 & 0 \\
\hline & 28 & 5491 & $P$ & 95.3 & 17.2 & 0 & 0 \\
\hline & 29 & 5492 & $P$ & 75.4 & 19.1 & 0 & 0 \\
\hline & 30 & 5885 & $T$ & 65.9 & 11.9 & 0 & 0 \\
\hline & 31 & 5889 & $P$ & 81.3 & 0.4 & 0 & 0 \\
\hline & 32 & 5891 & $T$ & 7.5 & 54.3 & 0 & 0 \\
\hline \multirow[t]{3}{*}{ Northern Iraq } & 33 & 5475 & $P$ & 72.8 & 43.0 & 0 & 0 \\
\hline & 34 & 5472 & $T$ & 66.2 & 6.0 & 0 & 0.2 \\
\hline & 35 & 5482 & $P$ & 34.0 & 4.1 & 0 & 0 \\
\hline
\end{tabular}

${ }^{\mathrm{a}} P$, var. polyathera; $T$, var. typica

${ }^{\text {b} T e s t e r ~ A, ~ K U 6-2, ~ v a r . ~ t y p i c a ~ f r o m ~ S y r i a ; ~ T e s t e r ~ B, ~ K U 5852, ~ v a r . ~ p o l y a t h e r a ~ f r o m ~ C e n t r a l ~ A n a t o l i a ; ~}$

Tester C, KU5864, var. typica from West Anatolia; Tester D, KU5871, var. typica from Greece 


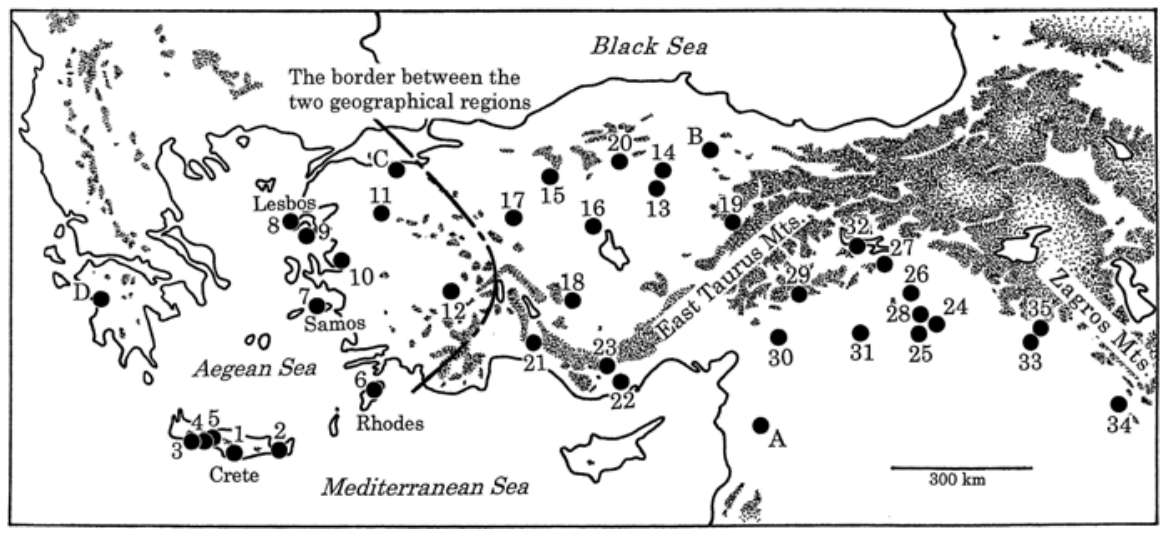

Fig. 6.1 Collection sites of the four Testers (A, B, C and D) and 35 accessions of Ae. caudata used in the present study (Ohta 2000). Mountainous area higher than $1,500 \mathrm{~m}$ above sea level is shadowed. A broken line indicates the border between the western and eastern regions defined from hybrid sterility

fertility in the $F_{1}$ hybrids, the 39 accessions including the four Testers could be grouped into the western and eastern geographical groups: the former consists of the accessions from the Greek mainland, the Aegean Islands and West Anatolia, while the latter from Central Anatolia, South Anatolia, East Anatolia, northern Syria and Iraq. The two geographical regions are isolated with the mountains lying between West Anatolia and Central Anatolia (Fig. 6.1).

\section{Gametocidal-Like Genes Cause the Sterility in Intraspecific $F_{1}$ Hybrids}

The highly sterile $\mathrm{F}_{1}$ hybrids from the two cross combinations between the parental lines derived from the western and eastern regions were backcrossed to their parental lines. The $\mathrm{BC}_{1} \mathrm{~F}_{1}$ plants distinctly restored their fertility when the $\mathrm{F}_{1}$ hybrids were backcrossed to the western parents, while their fertility was not restored when they were backcrossed to the eastern parents (Table 6.2). A similar sterility has been reported in several Aegilops species as the phenomenon that certain Aegilops chromosomes, gametocidal chromosomes, were preferentially transmitted in the genetic background of common wheat (Endo and Tsunewaki 1975; Maan 1975; Endo 1990). An Ae. caudata chromosome was found to be selectively retained in common wheat (Endo and Katayama 1978). Monosomic addition plants for a gametocidal chromosome to common wheat showed semi-sterility because only gametophytes with a gametocidal chromosome are functional while those without this chromosome are aborted. As a result, gametocidal chromosomes were preferentially transmitted to the next generation. When normal common wheat plants with 


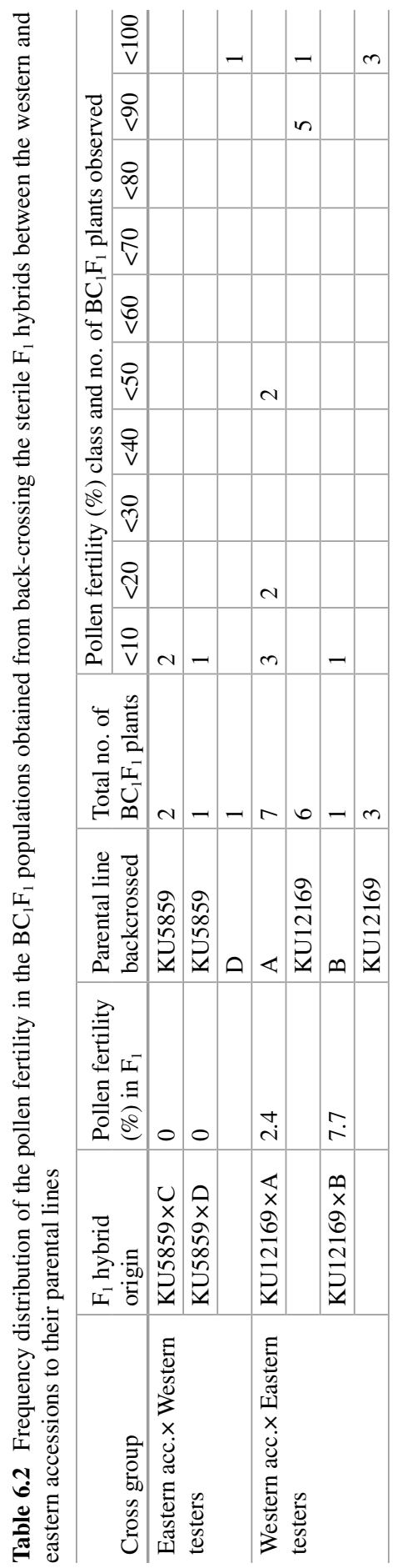




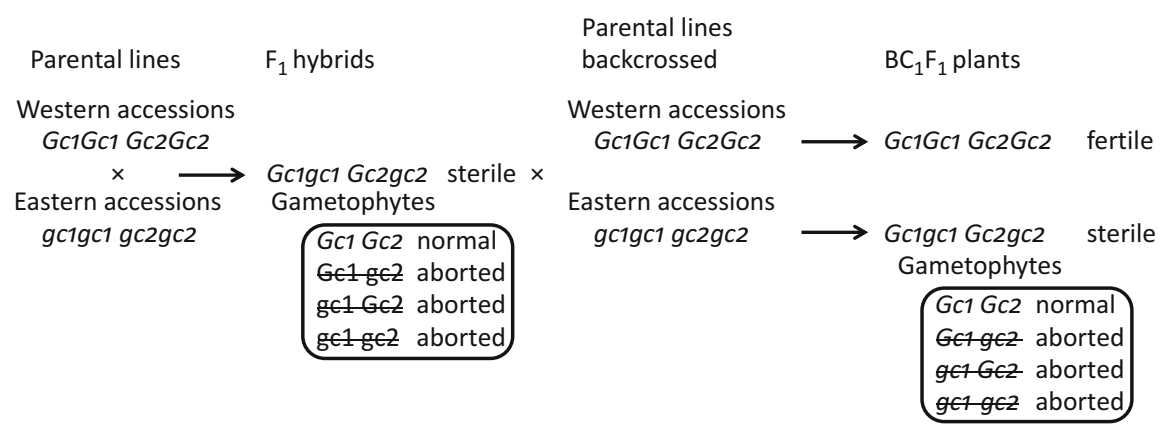

Fig. 6.2 A schema of the present gametocidal gene hypothesis explaining hybrid sterility in the $\mathrm{F}_{1}$ hybrids between the western and eastern accessions and its restoration in the $\mathrm{BC}_{1} \mathrm{~F}_{1}$ plants obtained from backcrosses to the western parental lines

42 chromosomes were crossed to the monosomic addition plants, the obtained plants had 43 chromosomes (monosomic addition for gametocidal chromosome) and showed semi-sterility again. Disomic addition plants for gametocidal chromosomes showed normal fertility, and such chromosomes were transmitted in stable by self-pollination.

In the present study, a similar phenomenon as that caused by gametocidal chromosomes in wheat genetic background was observed in the $\mathrm{F}_{1}$ and $\mathrm{BC}_{1} \mathrm{~F}_{1}$ plants of Ae. caudata with normal chromosome constitution, $2 n=14$. This result strongly suggests that the sterility in the $\mathrm{F}_{1}$ hybrids between the western and eastern accessions is caused not by gametocidal chromosomes but by certain gene $(s)$ on gametocidal chromosomes, and that gametocidal gene(s) cause sterility and their preferential transmission in heterozygotes not only in the genetic background of common wheat but also in the normal genetic background in Ae. caudata. A schema of the present gametocidal gene hypothesis explaining hybrid sterility is shown in Fig. 6.2, where we propose that the western and eastern accessions carry dominant and recessive gametocidal alleles, respectively.

\section{Genetic Control of the Diagnostic Morphology of the Two Varieties}

Two varieties collected at the nine sympatric stands on the Aegean Islands were crossed reciprocally with each other. All the $\mathrm{F}_{1}$ hybrids had awnless lateral spikelets and their pollen fertility was normal (Ohta 1992). The segregation of the awn character in the $F_{2}$ generation did not significantly deviate from 3 (awnless): 1 (awned) ratio (Table 6.3). This result indicates that a dominant inhibitor controls awnless lateral spikelets characteristic of var. typica.

Further, 13 typica accessions including Testers A (KU6-2), C (KU5864) and D (KU5871) were crossed with a common polyathera Tester B (KU5852) (Table 6.1) 
Table 6.3 The segregation of the awn character on lateral spikelets in the $F_{2}$ populations derived from fertile reciprocal $F_{1}$ hybrids between two varieties collected at their sympatric stands (Ohta 2001)

\begin{tabular}{l|l|l|l|l}
\hline & \multicolumn{4}{|l}{ No. of $_{2}$ plants observed $^{\mathrm{a}}$} \\
\cline { 2 - 5 } Population no. & Total & Awnless & Awned & $\chi 2(3: 1)$ \\
\hline $1982-6-11-1$ & 48 & 33 & 15 & 1.00 \\
\hline $1982-6-12-2$ & 86 & 63 & 23 & 0.13 \\
\hline $1982-6-12-4$ & 49 & 35 & 14 & 0.82 \\
\hline $1982-6-12-7$ & 72 & 59 & 13 & 1.85 \\
\hline $1982-6-14-7$ & 89 & 71 & 18 & 2.03 \\
\hline $1982-6-14-8$ & 63 & 49 & 14 & 0.26 \\
\hline $1982-6-14-9$ & 48 & 35 & 13 & 0.11 \\
\hline $1982-6-17-1$ & 69 & 55 & 14 & 0.82 \\
\hline $1982-6-23-1$ & 71 & 53 & 18 & 0.04 \\
\hline
\end{tabular}

${ }^{a}$ Data from reciprocal crosses were pooled

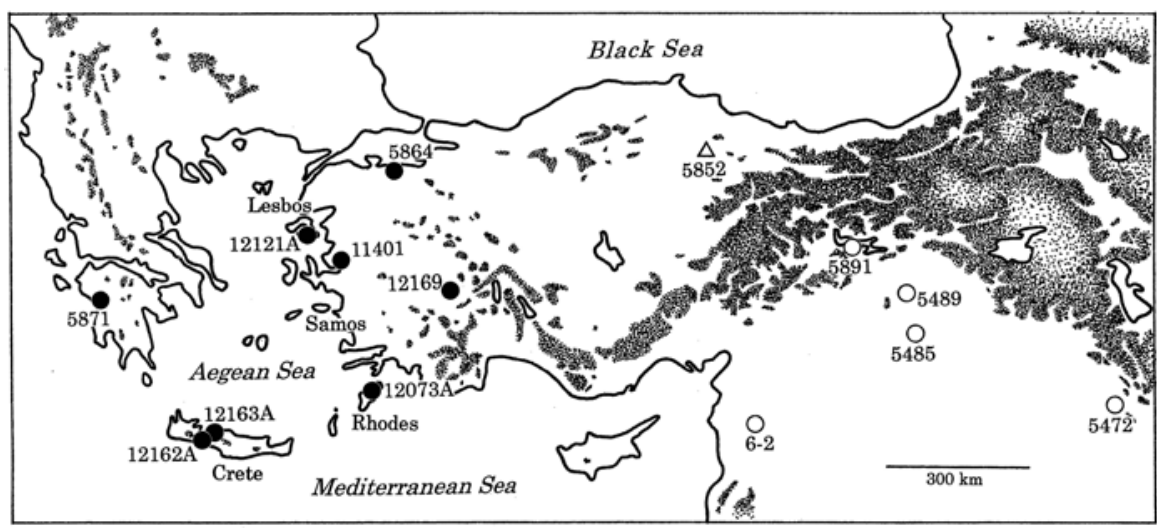

Fig. 6.3 Geographical distribution of the dominant and recessive typica accessions (Ohta 2001). Solid circles: dominant typica accessions, open circles: recessive typica accessions, and an open triangle: a common polyathera accession (Tester B: KU5852) used in the crosses. The figures indicate the accession numbers of Kyoto University

(Ohta 1992, 2000). These 13 typica accessions could be divided into the dominant and recessive typica accessions based on the spike morphology of the $F_{1}$ hybrids (Fig. 6.3). The $F_{1}$ hybrids involving the eight accessions from the western region were var. typica, while those involving the five accessions from the eastern region were var. polyathera. It is suggested that dominant typica accessions in the western region are controlled by a dominant inhibitor of the awns on lateral spikelets, while recessive typica accessions in the eastern region are controlled by recessive allele(s) for awn development on lateral spikelets. 


\section{Geographical Differentiation and Establishment of the Present Geographical Distribution in Ae. caudata}

The present distribution area of Ae. caudata can be divided into the western and eastern regions with the border in the mountains lying between West Anatolia and Central Anatolia. And the western and eastern accessions are isolated not only geographically by the mountains but also reproductively by hybrid sterility caused by gametocidal-like genes. The morphology of var. typica is controlled by two different genotypes in the western and eastern regions, so the division of the two taxonomic varieties based on the awn character on lateral spikelets is not so significant for the phylogeny of the species.

The distinct genetic differentiation between the western and eastern groups strongly suggests that the two geographical groups were isolated for a long term in the past. In the maximum glacial period from $18,000 \mathrm{BP}$ to $16,000 \mathrm{BP}$, steppe and desert-steppe with Artemisia and Chnopodiaceae covered the greater part of the Near East (van Zeist and Bottema 1991), which is now the primary diversity center of the wild Triticum and Aegilops species. Ae. caudata did not occur in Central Anatolia and East Anatolia in that period, and its distribution area might be divided into the two isolated refuges. One was the region surrounding the Aegean Sea where the climate was affected by the sea and was not excessively cold or dry, and the other was the western Levant or some sheltered habitats in the East Taurus/Zagros mountain arc. As the climate became warmer after the last glacial period, Ae. caudata penetrated Central Anatolia and East Anatolia with the spread of oak woodland from the latter refuge region, and now occupies the eastern region of the distribution. Variety polyathera with many awns on spikes might be advantageous to such a rapid colonization to new open habitats. The western region of the present distribution was established by the populations in the Aegean Sea region during the last glacial period.

Acknowledgments The authors thank the Plant Germ-plasm Institute, Kyoto University for the materials. These materials are now preserved and provided by the National BioResouce Project (NBRP)-WHEAT, Japan.

Open Access This chapter is distributed under the terms of the Creative Commons Attribution Noncommercial License, which permits any noncommercial use, distribution, and reproduction in any medium, provided the original author(s) and source are credited.

\section{References}

Bor NL (1968) Gramineae. In: Townsend CC, Guest E, Al-Rawi A (eds) Flora of Iraq 9. Ministry of Agriculture, Bagdad, pp 1-588

Bor NL (1970) Gramineae-Triticeae. In: Rechinger EH (ed) Flora Iranica 70. Academische Druck-u. Verlagsanstalt, Graz, pp 147-244 
Davis PH (1965) Flora of Turkey and the East Aegean Islands 1. Edinburgh University Press, Edinburgh, p 567

de Halácsy E (1904) Conspectus florae Graecae 3. Sumptibus Guilelmi Engelmann, Lipsiae

Eig A (1929) Monographisch-Kritische Übersicht der Gattung Aegilops. Repert Spec Nov Regni Veg 55:1-228

Endo TR (1990) Gametocidal chromosomes and their induction of chromosome mutations in wheat. Jpn J Genet 65:135-152

Endo TR, Katayama Y (1978) Finding of a selectively retained chromosome of Aegilops caudata L. in common wheat. Wheat Infom Serv 47-48:32-35

Endo TR, Tsunewaki K (1975) Sterility of common wheat with Aegilops triuncialis cytoplasm. J Hered 66:13-18

Hammer K (1980) Vorarbeiten zur monographischen Darstellung von Wildpflanzensortimenten: Aegilops L. Kulturpflanze 28:33-180

Hayek A (1927) Prodromus florae peninsulae Balcanicae. Repert Spec Nov Regni Veg 30:1-472

Maan SS (1975) Exclusive preferential transmission of an alien chromosome in common wheat. Crop Sci 15:287-292

Ohta S (1992) Intraspecific hybrid sterility in Aegilops caudata L. Hereditas 116:247-251

Ohta S (2000) Genetic differentiation and post-glacial establishment of the geographical distribution in Aegilops caudata L. Genes Genet Syst 75:189-196

Ohta S (2001) Variation and geographical distribution of the genotypes controlling the diagnostic spike morphology of two varieties of Aegilops caudata L. Genes Genet Syst 76:305-310

Rechinger KH (1943) Flora Aegaea. Denkschr Akad Wiss Wien Math-Nat Kl 105:1-924

Sakamoto S (1986) A preliminary report of Kyoto University ethnobotanical exploration to Greece and Turkey in 1982. Report of the Plant Germ-plasm Institute, Kyoto University 7, Kyoto, p 73

Tanaka M (1983a) Geographical distribution of Aegilops species based on the collections at the Plant Germ-plasm Institute, Kyoto University. In: Sakamoto S (ed) Proceedings of the 6th International Wheat Genetics Symposium, Kyoto, pp 1009-1024

Tanaka M (1983b) Catalogue of Aegilops-Triticum germ-plasm preserved in Kyoto University. Plant Germ-plasm Institute, Kyoto University, Kyoto, p 179

Tanaka M, Suemoto H, Ichikawa S (1967) The awn characters and sterility in Aegilops caudata L., I. Jpn J Breed 17(2):155-156

Tutin TG, Humphries CJ (1980) Aegilops L. In: Tutin TG, Heywood VH, Burges NA et al (eds) Flora Europaea 5. Cambridge University Press, Cambridge, pp 200-202

van Slageren MW (1994) Wild wheats: a monograph of Aegilops L. and Amblyopyrum (Jaub. \& Spach) Eig. Agricultural University, Wageningen, p 512

van Zeist W, Bottema S (1991) Late Quaternary vegetation of the Near East. Beihefte zum Tübinger Atlas des Vorderen Orients Reihe A 18:1-156

Zhukovsky PM (1928) A critical-systematical survey of the species of the genus Aegilops L. Bull Appl Bot Genet Plant Breed 18:417-609 